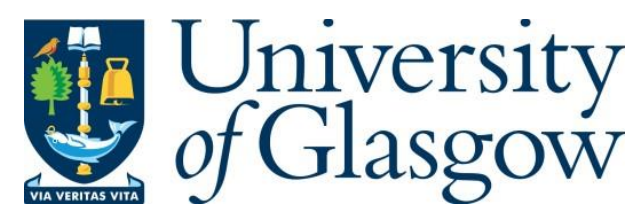

Stratigos, M. J. (2016) The lost lochs of Scotland: tracking land-use change and its effects on the archaeological record. Journal of Wetland Archaeology, 16(1), pp. 33-51.

There may be differences between this version and the published version. You are advised to consult the publisher's version if you wish to cite from it.

http://eprints.gla.ac.uk/145495/

Deposited on: 08 August 2017

Enlighten - Research publications by members of the University of Glasgow http://eprints.gla.ac.uk 
The Lost Lochs of Scotland: Tracking land-use change and its effects on the archaeological record

\author{
Michael J. Stratigos
}

Department of Archaeology, University of Aberdeen, Aberdeen, UK

Department of Archaeology, St. Mary's, Elphinstone Road, University of Aberdeen, Aberdeen, Scotland, AB24 3UF

Email: m.stratigos.08@aberdeen.ac.uk

ORCiD: 0000-0001-9284-9041

Biographical Note:

Michael is a PhD candidate at the University of Aberdeen due to be completed in 2017. His research focuses on crannogs and underwater archaeology in Scotland.

Word Count: 7237 


\title{
The Lost Lochs of Scotland: Tracking land-use change and its effects on the archaeological record
}

\author{
Michael J. Stratigos \\ Department of Archaeology, University of Aberdeen, UK
}

\begin{abstract}
This paper examines how loch drainage in $18^{\text {th }}$ and $19^{\text {th }}$ century Scotland has shaped the archaeological record, with particular reference to lake dwellings known as 'crannogs'. The analysis uses the Roy Military Survey of Scotland (1747-55) as a base-line for charting changes to lacustrine environment through time. The work is unique for its scale which examines all of mainland Scotland, and the results have revealed unrecognised patterns in the timing and intensity of land-use changes that have impacted lacustrine environments. These patterns are linked to the development of archaeological investigation in Scotland demonstrating that the current distribution of crannogs across the country is an artefact of loch drainage and antiquarian investigation and not representative of the past distribution of these critical sites. This paper presents one way in which we can begin to account for these historic changes to land-use and their impact to our understanding of the archaeological record.
\end{abstract}

Keywords: loch drainage, crannogs, Scotland, Improvement period, Roy Map, agricultural practices, wetland environment, lake dwellings

\section{Introduction}

Wetland archaeological research has often focused on threats to the archaeological record from modern changes to the landscape and burial environment (e.g. Buckland, 1993; Chapman and Cheetham, 2002; Matthiesen et al. 2004; Holden et al. 2006; Mallim et al. 2015; Matthiesen, 2015). At the same time, the quality and volume of material discovered through historic and contemporary changes to wetland landscapes has been widely recognised. However, quantifying historic land-use changes and their impact on the 
archaeological record is less often examined, and has tended to be conducted piecemeal through site-specific work (e.g. Larsson, 2007 and references therein). Over the past 300 years, Scotland, along with much of the rest of Europe, has undergone fundamental changes to its landscape associated with the development of agricultural practices. Conservation and ecology has routinely quantified, on a broad scale, the impact of modern and historic anthropogenic changes to wetland environments which are particularly sensitive to these changes (Naiman and Dudgeon, 2011: 868). Similar scale assessments in wetland archaeology are mostly lacking, and just as there are greater levels of biodiversity to be lost through changes to wetlands (see Brinson and Malvárez, 2002; Strayer and Dudgeon, 2010; O'Connell et al. 2012), there is also more in the archaeological record to be lost compared to dry-land sites (see Matthiesen et al. 2004; Brunning, 2012). Assessment of the fundamental changes associated with the transition to modern agricultural practices and the impact they have had on the archaeological record are needed on a far larger scales to account for the varied nature of these losses.

This paper begins to address the lack of broad-scale quantified assessment of historic changes to wetland environments within archaeological research, and presents an assessment of changes over the last 300 years to the lacustrine environment of Scotland. The study analyses how landscapes dramatically changed over the last three centuries through the practice of drainage and charts physical changes to lacustrine environments through time as a way of quantifying impacts on the archaeological record. The methodology presented here utilizes Scotland's extensive historic mapping resources as the primary dataset for analysis. This approach is unique in its scale which for the first time has allowed for insights into the patterns of change to the landscape across Scotland and how these changes have shaped the archaeological record as well as the trajectory of archaeological research in these environments. A characterisation of the effects on the archaeological record has been enabled by this work that was not possible before due to the site-specific nature of research of this kind. The data presented has significant implications for our understanding of Scotland's inland water archaeological resource, most notably the artificial island dwelling tradition of Scotland - the crannog. The importance of historic drainage lies not only in its objective impact to the archaeological record, but also in how it has been responsible for the nature, texture and distribution of the archaeological record in wetland environments. This is not 
unique to Scotland, and the wider European context of wetland environment and wetland archaeology loss will be highlighted.

\section{Improvement Period Land-use Changes}

Throughout Europe the rural landscape is largely a result of the last few centuries of development in agricultural practices. In Britain, these developments occurred mostly in the $18^{\text {th }}$ and $19^{\text {th }}$ centuries and is known as the 'Improvement period'. This period stands out in the development of agriculture for the adoption of similar practices across Britain including the introduction of multiple crop planting regimes, changes in land holding and tenancy agreements, the enclosing of arable and grazing lands, and drainage (Tarlow, 2007: 36-7). The Scottish Improvement saw all of the same changes in agricultural practice, but the period is considered to have started later than elsewhere in Britain. Scotland's agrarian economy remained feudal in many respects until after union with England in 1707, with the highlands and north-east lowlands remaining essentially feudal until the defeat of the Jacobite rebellion in 1746 (Davidson, 2004a: 230). The result was that Improvement agricultural practices were

implemented rapidly in the second half of the $18^{\text {th }}$ century, usually with land-owners adopting and implementing these new practices wholesale across their estates (Davidson, 2004b: 420-1). Most scholarship of this period was limited to the disciplines of human geography and economic history, but the past two decades have seen sustained archaeological interest, most frequently with a landscape approach (see Kay, 1962; Adams, 1968; Dalglish, 2003; Dixon 2007; Dixon and Gannon, 2008).

Wetland drainage and land reclamation has been a common practice in northern Europe for more than a millennium, and the intensity and scale of these drainage programmes has typically peaked in the $19^{\text {th }}$ century (e.g. wetland drainage in the Netherlands, see Hoeksema, 2007; van Beek et al. 2015). The importance of drainage in Improvement Scotland is seen in every edition of the Agricultural Surveys of Scotland, published between 1795 and 1814, that outline drainage as the first step of improvement. In the survey of Forfarshire, eastern Scotland, for example, it is remarked that, "[Drainage] is the first and most necessary of all improvements, without which, manures and labour upon land, are absolutely thrown away" (Headrick, 1813: 390). The phenomenon of loch (lake) drainage is remarkable for the lengths and expense to which proprietors and tenants went to achieve their 
aims - the same survey recorded that in 1746 the Loch of Kinnordy, Angus was drained by cutting through 30 to 40 feet (9.1 to 12.2 metres) in depth of sandstone to access 300 acres ( 121 ha) of good marl [a calcium rich sediment used to raise the $\mathrm{pH}$ of acidic soils] (ibid.: 27-8). Despite the practice of drainage being well-known historically, there has been no quantification of drainage from the $18^{\text {th }}$ and early $19^{\text {th }}$ centuries on anything more than a sitespecific scale in Scotland. Our resulting understanding of how drainage has impacted the archaeological record remains disparate with comparisons across regions difficult to draw.

\section{Drainage and Impacts to the Archaeological Record}

The impact changes in land-use had on the archaeological record in Scotland are frequently cited (e.g. Dixon and Gannon, 2008; Boyle, 2009), but quantifying or mapping that impact has only recently been undertaken on a wider scale or in a systematic manner (see above; Dixon, 2007). It is well-established that drainage can result in the near total loss of archaeological sites and materials (Chapman and Cheetham, 2002). Changes in saturation levels are directly responsible for the quality of survival of archaeological material in these environments, and drainage for agriculture is by far the most common cause of changes in water level. Understanding drainage associated with contemporary land-use changes has been undertaken where pertinent to the taphonomy or management of particular sites or landscapes (e.g. Mallim et al. 2015), but quantifying historic drainage and how it has shaped the archaeological record on regional or national scales is much less frequent. However, it is apparent that regional variations in the survival of wetland archaeology can impact how we understand archaeological phenomena, as noted in conjunction with logboat finds in Scotland (Mowat, 1998: 30-2) or artefact finds from bogs in the Twente region of the Netherlands (van Beek et al. 2015: 22-4). Without testing the biases in survival patterns, the character of the archaeological record may not be representative, and resulting interpretations are built upon uncertain foundations.

An example will be outlined here demonstrating how differing patterns of loch drainage have impacted our understanding on the most important site-type of wetland archaeology in Scotland - the crannog. Over 500 of these artificial islands are known (Lenfert, 2012), and are frequently encountered as small islands or submerged mounds in lochs. In Scotland, the known distribution of crannogs, which sees high densities of sites in 
western regions and very few sites in eastern areas, has been viewed as significant and linked to wider interpretations of crannogs' date and function (Munro, 1882: 248-9; Henderson, 1998: 240-2, 2009: 39-40; Cavers, 2010: 26-36; Lenfert, 2013). The understood distribution has informed research strategies which have regularly targeted regions with a wellestablished crannog resource (e.g. Crone, 1993; Henderson et al. 2003; Henderson and Cavers, 2005; Cavers et al. 2011). Research on Scottish crannogs has focused on south-west Scotland, where the majority of $19^{\text {th }}$ century antiquarian investigation took place, and the Tayside region of Perthshire, central Scotland (Stratigos and Noble, 2014: 205-6). The role Improvement period loch drainage has played in impacting the distribution of crannog sites has been noted (Morrison, 1985: 2; Hale, 2007: 278), but this paper represents the first systematic quantification of loch drainage across Scotland. A better understanding of the impact land-use changes had at regional and national scales is imperative for understanding the biases and preservation of the archaeological record.

\section{Method}

\section{The Roy Military Survey of Scotland (1747-1755)}

In order to quantify loch drainage, this study used historic mapping as its primary source of information. Cartography was an essential part of the agricultural changes that began in the $18^{\text {th }}$ century, as large estates sought to maximize economic productivity of their land and tenants (for discussion see Adams, 1968; Boyle, 2009). In addition to estate mapping, there was also an increase in mapping at regional and national scales. One of the earliest and most ambitious of these was the Roy Military Survey of Scotland (1747-1755) (Roy, 2007) (hereafter RMS). The map was made following the 1745 Jacobite Rebellion as a strategy aid for the British army, and is the direct predecessor and inspiration for the Ordnance Survey (Britain's national mapping programme) which began in earnest in the $19^{\text {th }}$ century (Hewitt, 2010). The map covers all of mainland Scotland at a scale of one inch to 1000 yards $(2.54 \mathrm{~cm}: 914.4 \mathrm{~m}$, or approximately 1:36,000). Maps on a similar scale were not made of other parts of Britain for another half-century, and for this reason, the RMS was selected for this study. While $18^{\text {th }}$ and $19^{\text {th }}$ century estate maps provide excellent detail, their small scale and wide ranging production dates make them unsuitable for the large-scale analysis conducted here. The RMS's usefulness in assessing land-use and settlement patterns 
in a pre-Improvement landscape has been explored (see Whittington, 1986a; 1986b), and its potential regarding loch drainage and crannogs has been noted, but not pursued to any extent (Morrison, 1985: 2). The RMS was made just as the Improvement period was beginning (c. mid 18th century) and shows various instances of Improvement in action (e.g. Figure 1), but the fundamental landscape changes that were undertaken during the Improvement period had yet to begin fully. For this reason, the RMS is a key resource, and in Britain, unique in depicting a largely un-Improved landscape across the country at such a detailed scale. [Figure 1 near here]

Roy's map was made with relatively simple methods even by $18^{\text {th }}$ century standards, using traverses with a 50 foot $(15.24 \mathrm{~m})$ chain and a simple theolodite (Skelton, 1967: 7-9; Hewitt, 2010: 28). The measured traverses were taken to prominent features in the landscape and remaining detail sketched in from field notes. The director of the survey, William Roy, admitted the map was, 'more a magnificent military sketch, than a very accurate map' (Roy, 1785: 385-6). In particular, there is difficulty in relying on the depiction and labelling of settlement on the RMS, however, major landscape features seem to be depicted with more consistency in accordance with the purpose of the map as an aid for military movement (Skelton, 1967: 12-3; Whittington, 1986b). Due to the timing of its production and the totality of its coverage (all of mainland Scotland), the RMS can quantify the effects of the Improvement period from the middle of the $18^{\text {th }}$ century through comparison with more recent mapping. Other $18^{\text {th }}$ century maps do not have the requisite scale, detail or coverage to enable such analysis over as wide an area. The map is freely available online on the National Library of Scotland's website $<$ http://maps.nls.uk/roy/index.html $>$, which provides the map in an easily accessible format that also facilitates analysis (see Fleet and Kowal 2007).

\section{Analysis}

The analysis undertaken involved identifying each loch depicted on the map, and recording the georectified coordinates of the online version of the RMS. Lochs were then located on the First Edition of the Six Inch County Series of the Ordnance Survey (1843-1882) (also available on the National Library of Scotland's website $<$ http:// maps.nls.uk/os/index.html>). This edition of the Ordnance Survey was selected as it is the first to cover all of mainland Scotland at a sufficiently detailed scale. Each loch identified on 
the RMS was compared against this historic edition of the Ordnance Survey as 'Drained', 'Lowered', 'No Change', or 'Dammed'. The assessment was made again compared to the modern 1:25,000 edition of Ordnance Survey available through Edina Digimap, and each loch's British National Grid coordinate was recorded (see Tables 1, 2, Supplementary Material). Locating lochs depicted on the RMS required varying methods as the RMS has geometric inaccuracies of up to 5 miles $(8.05 \mathrm{~km})$ in some instances, although relative proportions are more accurate (Fleet and Kowal, 2007: 201). The primary method to locate lochs depicted on the RMS was to follow rivers and catchments to their source on the RMS and then repeat this pattern on the editions of the Ordnance Survey. Names of the lochs on the RMS were compared to names appearing on editions of the Ordnance Survey to aid confidence in their identification, however, not all lochs depicted on the RMS were named. The method of following rivers to their source echoes the technique used to create the RMS, whereby rivers were surveyed from the sea to source taking measurements to important landscape features (Skelton, 1967: 7-9; Gardiner, 1977: 441). Garden water features depicted on the RMS were excluded from the dataset. The method provided a temporally bound data set showing where and when drainage was taking place in Scotland from the middle of the $18^{\text {th }}$ century.

[Table 1 near here]

[Table 2 near here]

There are several potential factors that may bias the results of the methodology. First, the clarity and consistency of the RMS is poor in certain areas of the map (see Whittington, 1986a; 1986b for discussion). In many cases, there is not always an obvious interpretation of features depicted (including variable indications for open water), resulting in a level of uncertainty regarding whether the feature depicted represented a loch. However, this uncertainty affects only a small percentage of lochs, and every loch considered within the analysis can be viewed online (see Supplementary Material). A further potential bias regards the timing of the field surveys of the First Edition of the Six Inch County Series of the Ordnance Survey. For mainland Scotland, the earliest date of survey is 1843 in Wigtownshire, while the latest is 1877 in Argyllshire. This difference should be considered as the data from this edition of the Ordnance Survey are presented equally (i.e. as if at the same 
time). However, the difference between regions is lessened (1843-71) when comparing areas with high levels of drainage (see Supplementary Material).

\section{Patterns of Drainage}

The analysis identified 1795 lochs on the RMS. Of these, 1745 lochs (or their drained basins) were successfully located within the First Edition of the Six Inch County Series of the Ordnance Survey and a modern edition of the 1:25,000 Ordnance Survey (Figures 2, 3; Supplementary Material). The dataset reveals that drainage was taking place at different times across different regions of Scotland. Notably, lowland (below 200m Ordnance Datum Newlyn (ODN)) areas of the eastern half of Scotland saw far more intense drainage in contrast to more western and upland areas (Figures 4, 5). The data indicate that in most of lowland eastern Scotland, drainage took place in the $18^{\text {th }}$ century and during the first half of the $19^{\text {th }}$ century, prior to the production of the First Edition of the Six Inch County Series of the Ordnance Survey (surveyed and published between c. 1850 and 1860, see Supplementary Material). In south-west Scotland significant levels of drainage occurred both before and after the production of the First Edition of the Six Inch County Series of the Ordnance Survey. This suggests that loch drainage was still occurring frequently into the second half of the $19^{\text {th }}$ century (Figures 2, 3, 4). Reasons for why this variation exists remain unclear, but the data show differences in the timing and intensity of this Improvement period agricultural practice across the country.

[Figure 2 near here]

[Figure 3 near here]

[Figure 4 near here]

[Figure 5 near here]

Looking more closely, the differences in both timing and intensity of loch drainage was even greater, and the extent to which some regions' lacustrine environment was altered is particularly notable. In places, drainage was exhaustive. For example, areas of lowland (below $200 \mathrm{~m}$ ODN) in the modern administrative council of Moray saw $91 \%$ of lochs depicted on the RMS drained. The impact on the archaeological record of lowland Moray is likely to have been similarly dramatic. However, the most important detail to be drawn out of these results with regard to the archaeological record of these environments is the difference 
in intensity and timing of drainage across regions. For example, if Moray is compared to South Ayrshire (modern council areas with similar numbers of lochs identified on the RMS and similar geographies) we can see very dramatic differences in the levels of drainage in the two areas (Figure 6). The disparity in the intensity of drainage between Moray and South Ayrshire will have had a substantial impact on the survival of the archaeological record in these regions, and created rather different conditions for the survival of wetland archaeology and different contexts for modern investigation.

[Figure 6 near here]

The results from the analysis of the RMS show that the Scottish landscape, in particular much of what is currently arable land, was formerly far wetter than it is now. While this is not a startling observation in itself, this analysis allows for the first time quantified insight into the extent to which drainage patterns will have impacted the survival and recognition of wetland archaeological sites. The results can help shift our understanding of the impacts of this Improvement period land-use change by providing a quantified baseline of data for assessing regional and national patterns. This has added significance when viewed alongside the history of the development of wetland archaeology, which in Scotland, only saw sustained and rigorous investigation beginning in the second half of the $19^{\text {th }}$ century with the first investigations of crannog sites (see below). Antiquarian investigation of wetland archaeology was predicated on drainage, and therefore, the spatial and temporal patterns of drainage influenced where wetland archaeology became a target of investigation. With regard to crannogs, it seems clear that patterns of drainage have influenced modern research strategies and therefore continues to colour our interpretations of this important class of monument.

\section{Re-constructing Lost Lochs and Implications for the Archaeological Record}

In addition to mapping landscape change at the regional and national level, the data presented here can also help reconstruct former lochs at a more localised scale. Former shorelines can be extrapolated from a range of available data, including the Ordnance Survey Digital Terrain Model (5x5m grid), the Canmore database of archaeological sites and monuments in Scotland, written accounts of the lochs' former extent, and modern editions of the Ordnance Survey. Analysis of this type can help begin to reconstruct the former extent of 
now drained lochs and wetlands and their relation to the distribution of archaeological sites in these landscapes. A review of a number of individual examples has found that palaeoshorelines can confidently be proposed for some lochs.

A case study in the potential of what the methodologies of loch reconstruction can bring is the analysis of Loch Auchlossan, Aberdeenshire (depicted on the RMS at NJ 581005 online grid reference). The New Statistical Account of Scotland records the former extent of the loch, 'its waters had then reached the strongly fortified mound of Peel Bog" (Miller, 1845: 1050). Using the 5x5m Ordnance Survey Digital Terrain Model identifies a possible palaeoshoreline at $145 \mathrm{~m}$ ODN which coincides with the $19^{\text {th }}$ century description of the loch level (Figure 7). This palaeoshoreline is also concordant with an excavation of a trackway interpreted as being at the edge of the former loch (Sutherland, 1989). Mapping the sites in the area from the Canmore database demonstrate that there are no pre- $18^{\text {th }}$ century sites or artefacts found within the reconstructed loch. There is one exception, a mound called The Houff, which is recorded as a possible motte in the Canmore database. Yet the site demonstrates very few characteristics of a motte site (Yeoman, 1988: 130), and is located in the western end of the proposed former loch, $200 \mathrm{~m}$ from the excavated trackway. The site has the dimensions one might expect from a crannog in a drained loch, and accounts of quarrying activity there in the 1960s uncovered material consistent with a desiccated crannog - sands, ash, bone and clay. Evaluative excavation of a 1x3m trench in 2015 by the author revealed anthropogenic deposits make up the mound, but no waterlogged organic remains survive (Stratigos, 2015). Its location within the former loch and the excavation data are strong evidence for reclassifying this site as a probable crannog.

Wider analysis can also identify potential sites as crannogs which substantially alter the known number of crannogs sites in areas that have seen extensive drainage. The Houff is a part of a wider phenomenon - a range of terrestrial archaeological features recorded in the Canmore database of archaeological sites in Scotland within, or likely to be within, former lochs (Stratigos, 2016; Figure 8). In total, 78 sites recorded in the Canmore database of archaeological sites in Scotland from across the country have been identified as potential crannogs based on their recorded descriptions and location within lowered or former lochs across Scotland. 78 sites represent a $13 \%$ increase in the number of crannogs recorded in 
Scotland, and 35 of those 78 come from the eastern half of Scotland - a three-fold increase in the number of recorded crannogs in this region.

These sites, along with acknowledgement that many more sites are likely to have been entirely destroyed by drainage in eastern Scotland, significantly alters the distribution of crannogs across the country. The patterns of drainage also influenced antiquarian investigation of these sites. In the second half of the $19^{\text {th }}$ century, crannog sites were made accessible to investigation through significant levels drainage in south-west Scotland at that time, while in eastern Scotland, most lochs that were going to be drained, had been so for decades or more (see Figure 4). This can be seen most clearly in the work of Robert Munro whose investigation of crannogs took place solely in south-west Scotland in last decades of the $19^{\text {th }}$ century, and whose research still informs current interpretations (Munro, 1882; Dixon 2004: 60; Midgley \& Sanders, 2012). The distribution of crannogs, influenced heavily by patterns of drainage, has continued to shape the trajectory of research on crannogs even in the most recent programmes of work. The Scottish Wetland Archaeology Programme and the South-West Crannog Survey are responsible for the majority of recent work on crannogs and have intently focused on crannogs in south-west Scotland (Henderson et al. 2003, 2006; Cavers et al. 2011). Additionally, four $\mathrm{PhD}$ theses have examined crannogs in western Scotland, (Holley, 1997; Cavers, 2005; Lenfert, 2012; Jacobsson, 2015), but only one has considered sites in eastern Scotland and this focuses on the late medieval and post-medieval evidence (Shelley, 2009). Research has continually returned to western Scotland because there has been an existing dataset which can be traced back to Munro in the $19^{\text {th }}$ century. While this work has greatly increased our understanding of the site-type in the region, the degree to which these datasets are applicable to other regions is unclear, and making wider interpretations of the artificial island dwelling phenomenon in Scotland problematic. Most notably, the assertion that crannogs were predominately a phenomenon of western Scotland in later prehistory has been made (Henderson, 1998, 2009; Cavers, 2006, 2010; Henderson, 2009; Lenfert, 2013). If crannogs are recognised as being a building tradition constructed nearly ubiquitously wherever suitable loch conditions existed in Scotland in the first millennium $\mathrm{BC}$, then interpretations based on a western distribution of crannogs must be reassessed. As an unparalleled archaeological resource in terms of organic preservation of material, recognition of the 'lost' lochs and the archaeological traces of their former wetland 
sites may have significant implications well beyond crannogs for understanding detail normally lost in dry-land contexts.

\section{Discussion}

To fully understand the fundamental impacts that later land-use change had on the archaeological record we must begin to more broadly document the ways in which practices such as drainage have altered and biased our perceptions of the character and distribution of archaeological material. What we can we say about wetland archaeological material with regard to their spatial characteristics is unquestionably impacted by later land-use changes. Crucially, land-use changes vary at regional and national scales, resulting in bias in our understanding of the character and distribution of archaeological sites as demonstrated here with crannogs. The sub-discipline of wetland archaeology has long recognised the significant impact drainage can have on waterlogged deposits, but this recognition has led mostly to strategies for the mitigation of further impacts rather than quantifying and mapping areas of wetland loss (e.g. Van de Noort et al. 2002; van Heeringen \& Theunissen, 2007; Bunting et al. 2014). This paper is a first step towards a quantified record of land-use changes in Scotland that caused major losses to the archaeological record which for the first time can be examined and tested in a systematic way at a national scale.

Similar to Scotland, high rates of wetland loss can be identified in other areas of Europe, and development in agricultural practices has most frequently been the main cause of these changes (Brinson \& Malvárez, 2002: 120-4). Investigating the trajectories of land-use changes in regions impacted by drainage will undoubtedly repay investigation especially where the timing and location of these changes have been directly implicated in the creation the archaeological record (eg. Middle and Late Bronze Age metalwork deposition in the Muese Valley, Netherlands - Fontijn, 2012: 51-2). Characterising and mapping the texture of these changes and the factors responsible on more than a local or regional scale can reveal important patterns regarding the formation of the archaeological record in wetland environments that may throw light on how later investigation of such material progressed. In this way, an account can be made for the biases that have become inherent in the archaeological record due to land-use change. The methodologies used in this research are applicable in areas where suitable cartographic records exist, and can be coupled with 
existing or new palaeoenvironmental research. Moreover, with better understanding of the real distribution of particular categories of archaeological material, targeted research and broader research frameworks can begin to systematically tackle the biases inherent in current archaeological understanding.

\section{Conclusion}

This study has outlined a large-scale quantification of the character and effect of the dramatic changes that Improvement brought to the landscape of Scotland and the consequent impact on our understanding of the archaeological record. This paper has developed a methodology that uses the RMS to track impacts to lacustrine environment from changes in land-use over the past $c .250$ years. These changes in Scotland have affected a near complete transformation of lacustrine environment in some regions. The archaeological record in these environments has been impacted similarly, and interrogating this impact has cast new light on our understanding of Scotland's most prominent inland water archaeological feature - the crannog. This paper demonstrates how broad scale palaeogeography of relatively recent landuse changes can provide important information for our understanding of earlier landscapes and the archaeology preserved (or destroyed) within them. Around the world, lacustrine and other wetland environments are under continued pressure from changes in land-use. These environments are increasingly being recognized for their importance in conservation, ecology, and human health frequently with little reference to their human history which in virtually all cases has significantly impacted them (see Dudgeon et al. 2006; Carpenter et al. 2011; Naiman and Dudgeon, 2011). The importance of wetland environments for archaeology is well established, but taking account of how historic changes have impacted the resource will help to develop the relevance of this resource in other contexts. Wetlands will continue to provide outstanding detail for our knowledge of the past through exceptional preservation conditions, but these environments can and should be examined on wider scales of analysis that might illuminate other anthropogenic changes to the landscape, their impact to the archaeological record and our understanding of it.

\section{Acknowledgements}


I wish to thank a number of people who have supported my endeavours in Scottish archaeology. First, to my parents who have made so much of this work possible. I must thank my partner Claire who has been a constant source of encouragement. Thanks go to my $\mathrm{PhD}$ supervisor, Gordon Noble, for his guidance and revisions of endless drafts of this paper, and to Jeff Oliver and Stewart Angus who commented on earlier drafts. And finally I must also thank Fraser Sturt under whose supervision the original idea for this research was developed. Any errors or omissions remain my own.

\section{References}

Adams, I.H. 1968. The land surveyor and his influence on the Scottish rural landscape. The Scottish Geographical Magazine, 84(3): 248-255.

Boyle, S. 2009. Mapping Landscapes of the Improvement Period: Surveys of North Lochtayside, 1769 and 2000. Scottish Geographical Journal, 125(1): 43-60.

Brinson, M.M. and Malavárez, A.I. 2002. Temperate freshwater wetlands: types, status, and threats. Environmental Conservation, 29(2): 115-33.

Brunning, R. 2012. Partial Solutions to Partially Understood Problems-The Experience of In Situ Monitoring and Preservation in Somerset's Peatlands. Conservation and Management of Archaeological Sites, 14(1): 397-405.

Buckland, P. 1993. Peatland archaeology: a conservation resource on the edge of extinction. Biodiversity and Conservation, 2(5): 513-27.

Bunting, C., Branch, N., Robinson, S. and Johnes, P. 2014. Ground penetrating radar as a tool to improve heritage management of wetlands. In: S. Lambot, A. Giannopoulos, L. Pajewski, F. André, E. Slob and C. Craeye eds. Proceedings of the $15^{\text {th }}$ International Conference on Ground Penetrating Radar 2014. New York: Curran Associates Inc., pp. 54-9.

Carpenter, S., Stanley, E. and Vander Zanden, P. 2011. State of the World's Freshwater Ecosystems: Physical, Chemical and Biological Changes. Annual Review of Environment and Resources, 36: 75-99.

Cavers, G. 2005. Crannogs and later prehistoric settlement in western Scotland. (unpublished $\mathrm{PhD}$ thesis, University of Nottingham). 
Cavers, G. 2006. Late Bronze and Iron Age Lake Settlement in Scotland and Ireland: the development of the 'crannog' in the north and west. Oxford Journal of Archaeology, 25(4): 389-412

Cavers, G. 2010. Crannogs and later prehistoric settlement in western Scotland. (British Archaeological Reports British series 510). Oxford: Archaeopress.

Cavers, G., Crone, B.A., Engel, R., Fouracre, L., Hunter, F., Robertson, J., and Thoms, J. 2011. Refining Chronological Resolution in Iron Age Scotland: Excavations at Dorman's Island Crannog, Dumfries and Galloway. Journal of Wetland Archaeology 10(1): 71-108.

Cavers, G. and Henderson, J. 2005. Underwater Excavation at Ederline Crannog, Loch Awe, Argyll, Scotland. International Journal of Nautical Archaeology, 34(2): 282-98.

Chapman, H.P. and Cheetham, J.L. 2002. Monitoring and modelling saturation as a proxy indicator for in situ preservation in wetlands - a GIS-based approach. Journal of Archaeological Science, 29(3): 277-89.

Crone, B.A. 1993. Crannogs and chronologies. Proceedings of the Society of Antiquaries of Scotland, 123: 245-54.

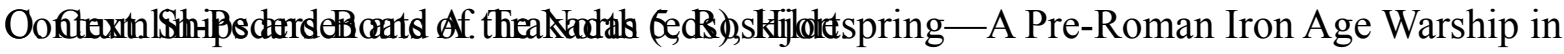
Dalglish, C. 2003. Rural society in the age of reason: an archaeology of the emergence of modern life in the southern Scottish highlands. New York: Kluwer Academic Publishers.

Davidson, N. 2004a. The Scottish Path to Capitalist Agriculture 1: From the Crisis of Feudalism to the Origins of Agrarian Transformation (1688-1746). Journal of Agrarian Change, 4(3): 227-268.

Davidson, N. 2004b. The Scottish path to capitalist agriculture 2: the capitalist offensive (1747-1815). Journal of Agrarian Change, 4(4): 411-60.

Dixon, N. 2004. Scottish Crannogs: an underwater archaeology. Stroud: Tempus Publishing Ltd.

Dixon, P. 2007. Conservation not reconstruction: Historic Land-use Assessment (HLA), or characterising the historic landscape in Scotland. Landscapes, 8(2): 72-83.

Dixon, P. and Gannon, A. 2008. The Transformation of the Rural Landscape. In: Royal Commission on the Ancient and Historic Monuments of Scotland ed. In the Shadow of Bennachie: A Field Archaeology of Donside, Aberdeenshire. Edinburgh: Society of Antiquaries of Scotland, pp. 215-44.

Dudgeon, D., Arthington, A., Gessner, M., Kawabata, Z., Knowler, D., Lévêque, C., Naiman, R., Prieur-Richard, A., Soto, D., Stisassny, M., and Sullivan, C. 2006. Freshwater biodiversity: importance, threats, status and conservation challenges. Biological Reviews, 81(2): 163-82. 
Fleet, C. and Kowal, K.C. 2007. Roy Military Survey Map of Scotland (1747-1755): mosaicing, geo-referencing, and web delivery. E-Perimetron, 2(4): 194-208.

Fontijn, D. 2012. Landscapes without boundaries? Some thoughts on Bronze Age deposition areas in North-West Europe. In: S. Hansen, D. Neumann and T. Vachta, eds. Hort und Raum. Aktuelle Forschungen zu bronzezeitlichen Deponierungen in Mitteleuropa, Berlin: De Gruyter, pp. 49-68.

Gardiner, R.A. 1977. William Roy, Surveyor and Antiquary. The Geographical Journal, 143(3): 439-50.

Hale, A. 2007. Crannogs in south-east Scotland. In: J. Barber, C. Clark, M. Cressey, A. Crone, A. Hale, J. Henderson, R. Housley, R. Sands, and A. Sheridan, eds. Archaeology from the Wetlands: Recent Perspectives. Proceedings of the 11th WARP Conference, Edinburgh, 2005. Edinburgh: Society of Antiquaries of Scotland, pp. 275-9.

Headrick, J. 1813. General View of the Agriculture of the County of Angus, or Forfarshire; with Observations on the Means of its Improvement; Drawn up for the Consideration of the Board of Agriculture and Internal Improvement. Edinburgh: D. Willison.

Henderson, J. 1998. Islets through time: the definition, dating and distribution of Scottish crannogs. Oxford Journal of Archaeology 17(2): 227-244.

Henderson, J. 2009. Taking the waters: Scottish crannogs and the Atlantic Iron Age. In: G. Cooney, K. Becker, J. Coles, M. Ryan and S. Sievers, eds. Relics of Old Decency: Archaeological Studies in Later Prehistory 2009. Dublin: Wordwell, pp. 39-48.

Henderson, J. and Cavers, G. 2005. Underwater Excavation at Ederline Crannog, Loch Awe, Argyll, Scotland. International Journal of Nautical Archaeology 34(2): 282-298.

Henderson, J., Cavers, G. and Crone, A. 2006. The south-west crannog survey: recent work on the lake dwellings of Dumfries and Galloway. Transactions of the Dumfriesshire and Galloway Natural History and Antiquarian Society, 80:29-51.

Henderson, J., Crone, B.A., and Cavers, G. 2003. A Condition Survey of Selected Crannogs in South-West Scotland. Transactions of the Dumfriesshire and Galloway Natural History and Antiquarian Society, 78: 79-102.

Hewitt, R., 2010. Map of a nation: A biography of the Ordnance Survey. London: Granta Books.

Hoeksema, R. 2007. Three Stages in the History of Land Reclamation in the Netherlands. Irrigation and Drainage, 56(S1): S113-26. 
Holden, J., West, L.J., Howard, A.J., Maxfield, E., Panter, I. and Oxley, J. 2006. Hydrological controls of in situ preservation of waterlogged archaeological deposits. Earth-Science Reviews, 78(1): 59-83.

Holley, M. 1997. The artificial islets of the central Inner Hebrides : first approaches. PhD thesis, University of Edinburgh.

Jacobsson, P. 2015. Improving the 14C dating of south-west Scottish wetland sites. $\mathrm{PhD}$ thesis, University of Edinburgh.

Kay, G. 1962. The landscape of improvement: A case study of agricultural change in NorthEast Scotland. The Scottish Geographical Magazine, 78(2): 100-11.

Larsson, L. 2007. Wetlands and major infrastructural programmes: prehistoric wetland sites in excavation project in Scania, southernmost Sweden. In: J. Barber, C. Clark, M. Cressey, A. Crone, A. Hale, J. Henderson, R. Housley, R. Sands, and A. Sheridan, eds. Archaeology from the Wetlands: Recent Perspectives. Proceedings of the 11th WARP Conference, Edinburgh, 2005. Edinburgh: Society of Antiquaries of Scotland, pp. 31-9.

Lenfert, R. 2012. Long-term continuity and change within Hebridean and mainland Scottish island dwellings. $\mathrm{PhD}$ thesis, University of Nottingham.

Lenfert, R., 2013. Integrating Crannogs and Hebridean Island Duns: Placing Scottish Island Dwellings Into Context. The Journal of Island and Coastal Archaeology, 8(1): 122-43.

Mallim, T., Morgan, D., and Panter, I. 2015. Suspended preservation: Particular preservation conditions within the Must Farm - Flag Fen Bronze Age landscape. Quaternary International, 368: 19-30.

Matthiesen, H., Salomonsen, E. and Sørensen, B. 2004. The use of radiography and GIS to assess the deterioration of archaeological iron objects from a waterlogged environment. Journal of Archaeological Science, 31(10): 1451-61.

Matthiesen, H. 2015. Detecting and quantifying ongoing decay of organic archaeological remains: A discussion of different approaches. Quaternary International, 268: 43-50.

Midgley, M.S. and Sanders, J. 2012. Munro and the Emergence of Archaeology. In M.S. Midgley and J. Sanders, ed. Lake Dwellings after Robert Munro. Leiden: Sidestone Press, pp. 17-36.

Miller, R. 1845. United Parishes of Aboyne and Glentanar. In: J. Sinclair ed. The Statistical Account of Scotland, Volume 12. Edinburgh: William Creech, pp. 1047-69.

Morrison, I. 1985. Landscape with lake dwellings: the crannogs of Scotland. Edinburgh: Edinburgh University Press. 
Mowat, R. 1998. The Logboat in Scotland. Archaeonautica, 14: 29-39.

Munro, R. 1882. Ancient Scottish Lake Dwellings or Crannogs. Edinburgh: Thomas and Archibald Constable.

Naiman, R., and Dudgeon, D. 2011. Global alteration of freshwaters: influences on human and environmental well-being. Ecological Research, 26(5): 865-73.

National Library of Scotland. First Edition of the Six Inch Ordnance Survey (1843-1882). http://maps.nls.uk/os/index.html (accessed 4 July 2016)

National Library of Scotland. Roy Military Map of Scotland (1747-1755). http://maps.nls.uk/ roy/index.html (accessed 4 July 2016)

O’Connell, J.L., Johnson, L.A., Smith, L.M., McMurry, S.T. and Haukos, D.A. 2012. Influence of land-use and conservation programs on wetland plant communities of the semiarid United States Great Plains. Biological Conservation, 146(1): 108-15.

Oliver, R. 1993. Ordnance Survey Maps; a concise guide for historians. London: The Charles Close Society.

Roy, W. 1785. An Account of the Measurement of a Base on Hounslow Heath. Philosophical Transactions of the Royal Society of London, 75: 385-478.

Roy, W. 2007. The Great Map: the Military Survey of Scotland 1747-55, with introductory essays by Yolande Hodson, Chris Tabraham and Charles Withers. Edinburgh: Birlinn.

Royal Commission on the Ancient and Historic Monuments of Scotland. http:// hlamap.org.uk/ (accessed 4 July 2016)

Reuter H.I., Nelson, A. and Jarvis, A. 2007. An evaluation of void filling interpolation methods for SRTM data. International Journal of Geographic Information Science, 21(9): 983-1008.

Shelley, M. 2009. Freshwater Scottish loch settlements of the Late Medieval and Early Modern periods; with particular reference to northern Stirlingshire, central and northern Perthshire, northern Angus, Loch Awe and Loch Lomond. PhD thesis, University of Edinburgh.

Skelton, R.A. 1967. The military survey of Scotland 1747-1755. The Scottish Geographical Magazine, 83(1): 5-16.

Stratigos, M.J. 2016. A Reconsideration of the Distribution of Crannogs in Scotland. In: Erskine, G.J.R., Jacobsson, P., Miller, P., Stetkiewicz, S. eds. 14th Iron Age Research Student Symposium, Edinburgh 29th May-1 ${ }^{\text {st }}$ June 2014. Oxford: Archaeopress, pp. 95-106. 
Stratigos, M.J. 2015. The Houff (Crannogs in NE Scotland: Ballater to Banchory). Discovery and Excavation in Scotland 16: 25.

Stratigos, M.J. and Noble, G. 2014. Crannogs, castles and lordly residences: new research and dating of crannogs in north-east Scotland. Proceedings of the Society of Antiquaries of Scotland, 144: 205-22.

Strayer, D.L. and Dudgeon, D. 2010. Freshwater biodiversity conservation: recent progress and future challenges. Journal of the North American Benthological Society, 29(1): 344-58.

Sutherland, K. 1989. Auchenhove, Lumphanan Parish. Discovery and Excavation in Scotland, p. 24.

Tarlow, S. 2007. The Archaeology of Improvement in Britain, 1750-1850. Cambridge: Cambridge University Press.

van Beek, R., Maas, G., J. and van den Berg, E. 2015. Home Turf: an interdisciplinary exploration of the long-term development, use and reclamation of raised bogs in the Netherlands. Landscape History, 36(2): 5-34.

Van de Noort, R., Fletcher, W., Thomas, G., Carstairs, I. and Patrick, D. 2002. Monuments at risk in England's wetlands. Exeter: University of Exeter.

Van Heeringen, R. and Theunissen, L. 2007. Archaeological monitoring of (palaeo) wetlands in the Netherlands: from best practice to guidelines. In: J. Barber, C. Clark, M. Cressey, A. Crone, A. Hale, J. Henderson, R. Housley, R. Sands, and A. Sheridan eds. Archaeology from the Wetlands: Recent Perspectives: Proceedings of the 11th WARP Conference, Edinburgh 2005. Edinburgh: Society Antiquaries Scotland, pp. 49-66.

Whittington, G. 1986a. The Roy map: The protracted and fair copies-Part One. The Scottish Geographical Magazine, 102(1): 18-28.

Whittington, G. 1986b. The Roy map: The protracted and fair copies-Part Two. The Scottish Geographical Magazine, 102(2): 66-73.

Yeomann, P. 1988. Mottes in Northeast Scotland. Scottish Archaeological Review 5: 125-33. 


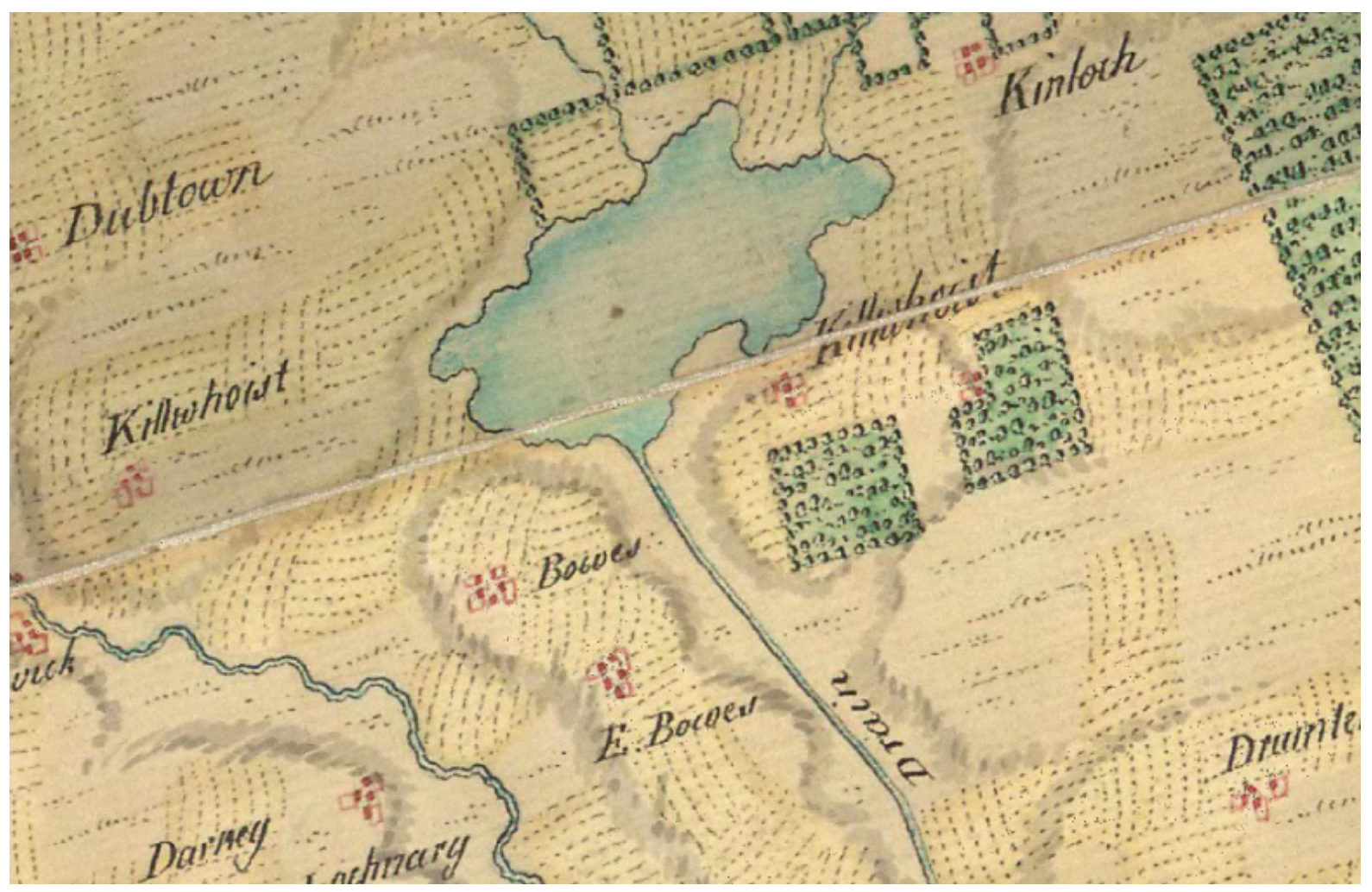

Figure 1 - Loch Rossie, Fife depicted on the RMS as it is being drained. Records for the drainage of this loch stretch back to the 1740 s, but seemingly is not completely drained until the 1750s. Sheets C.9.b 18/1a and C.9.b 18/2d C British Library Board. 

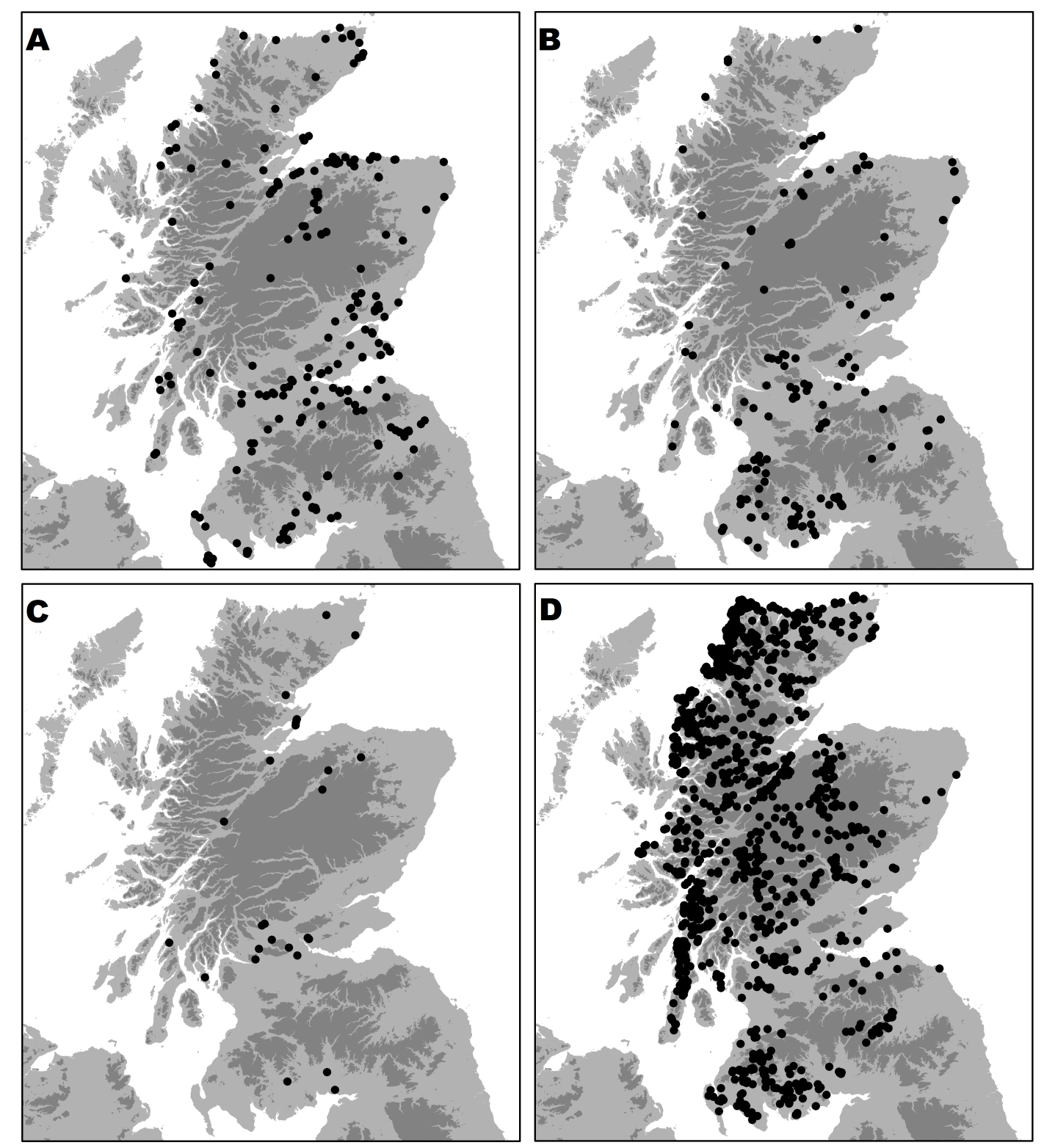

Figure 2 - State of lochs depicted on the RMS compared to $1^{\text {st }}$ Edition OS: A) Drained, B) Lowered, C) Dammed, D) No Change. 

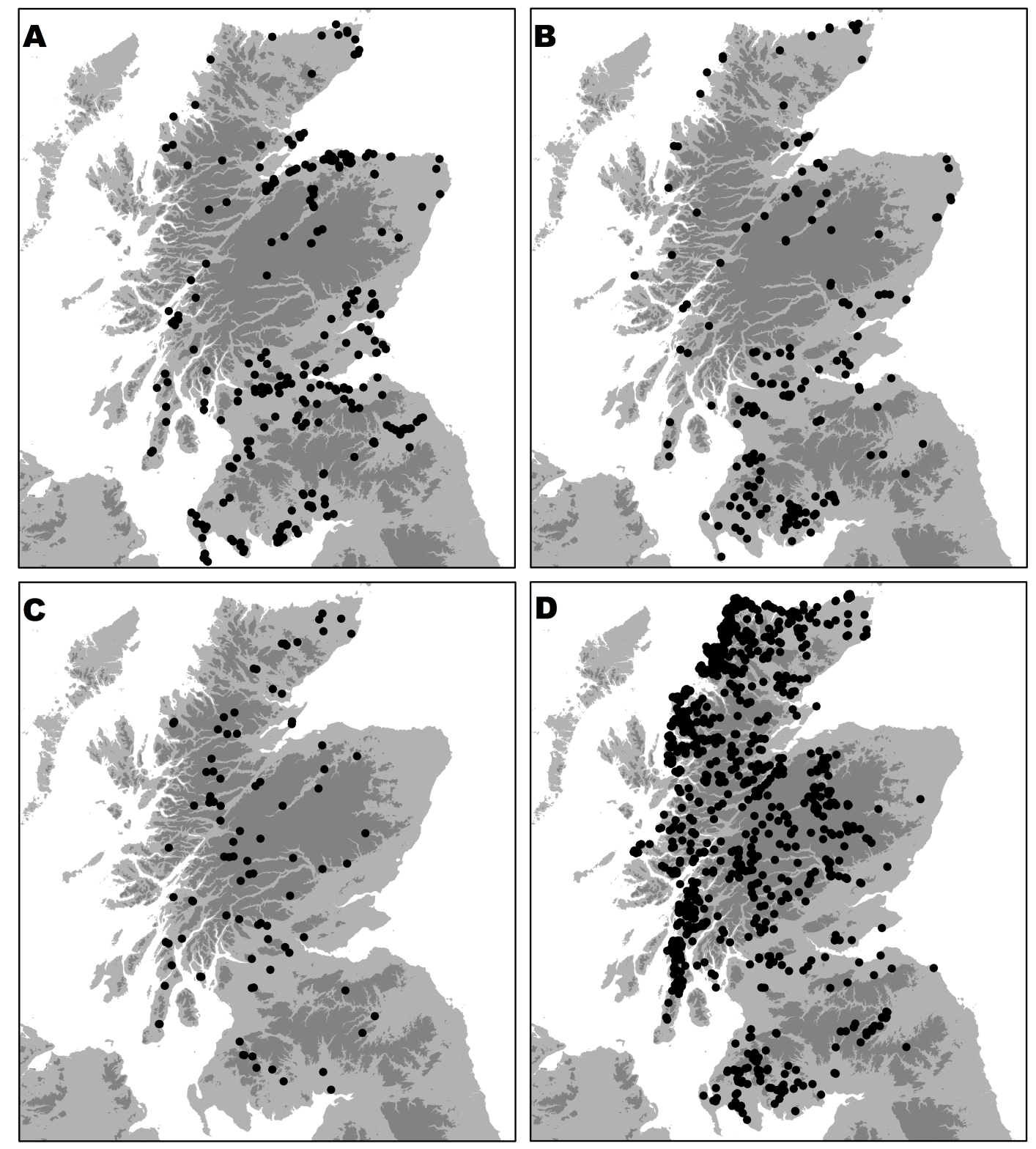

Figure 3 - State of lochs depicted on the RMS compared to Modern OS A) Drained, B) Lowered, C) Dammed, D) No Change. 


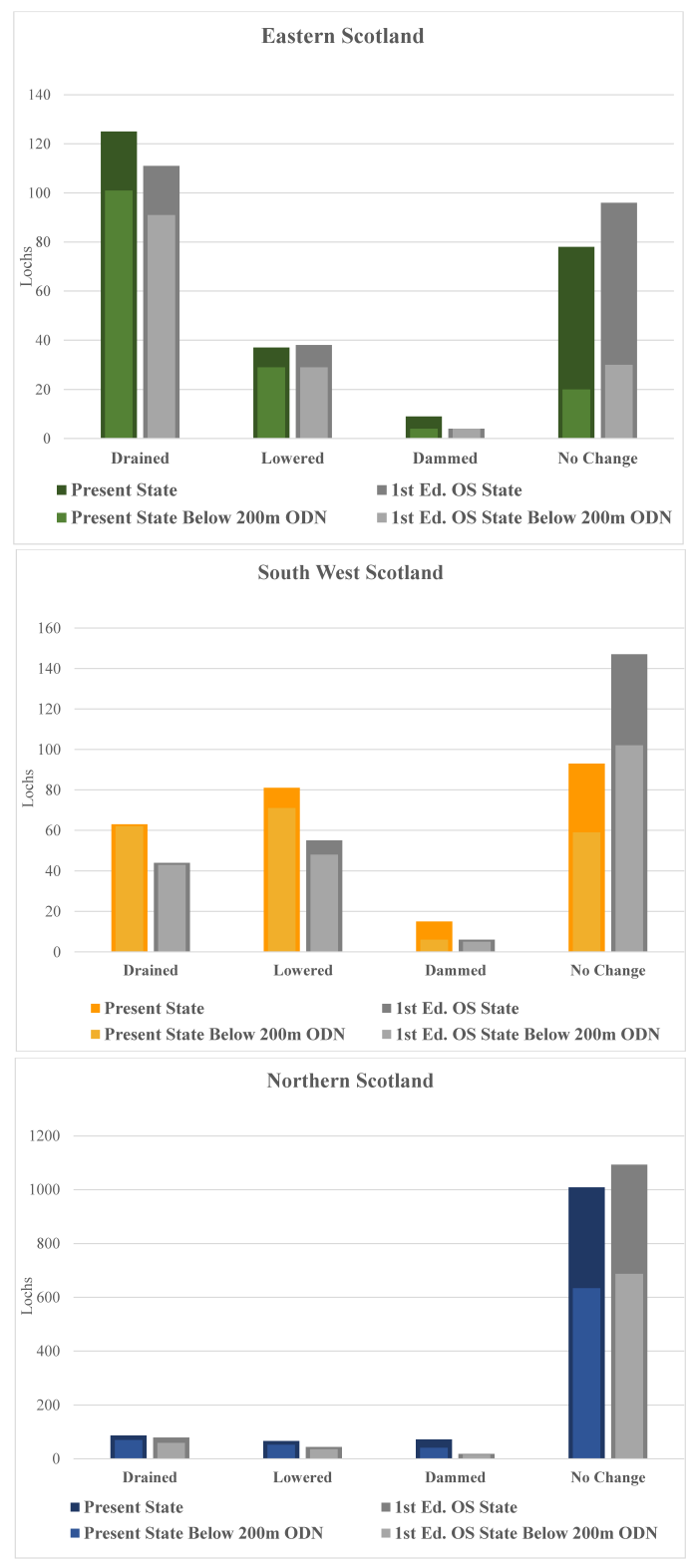

Figure 4 - Lochs that have been drained, lowered, dammed or no change since production of the RMS compared to the First Edition of the Six Inch County Series of the Ordnance Survey and modern mapping grouped by region (see Figure 5). Data for lochs below 200m is inset within the corresponding bar for all lochs. See Supplementary Material for dataset used to create graphs. 


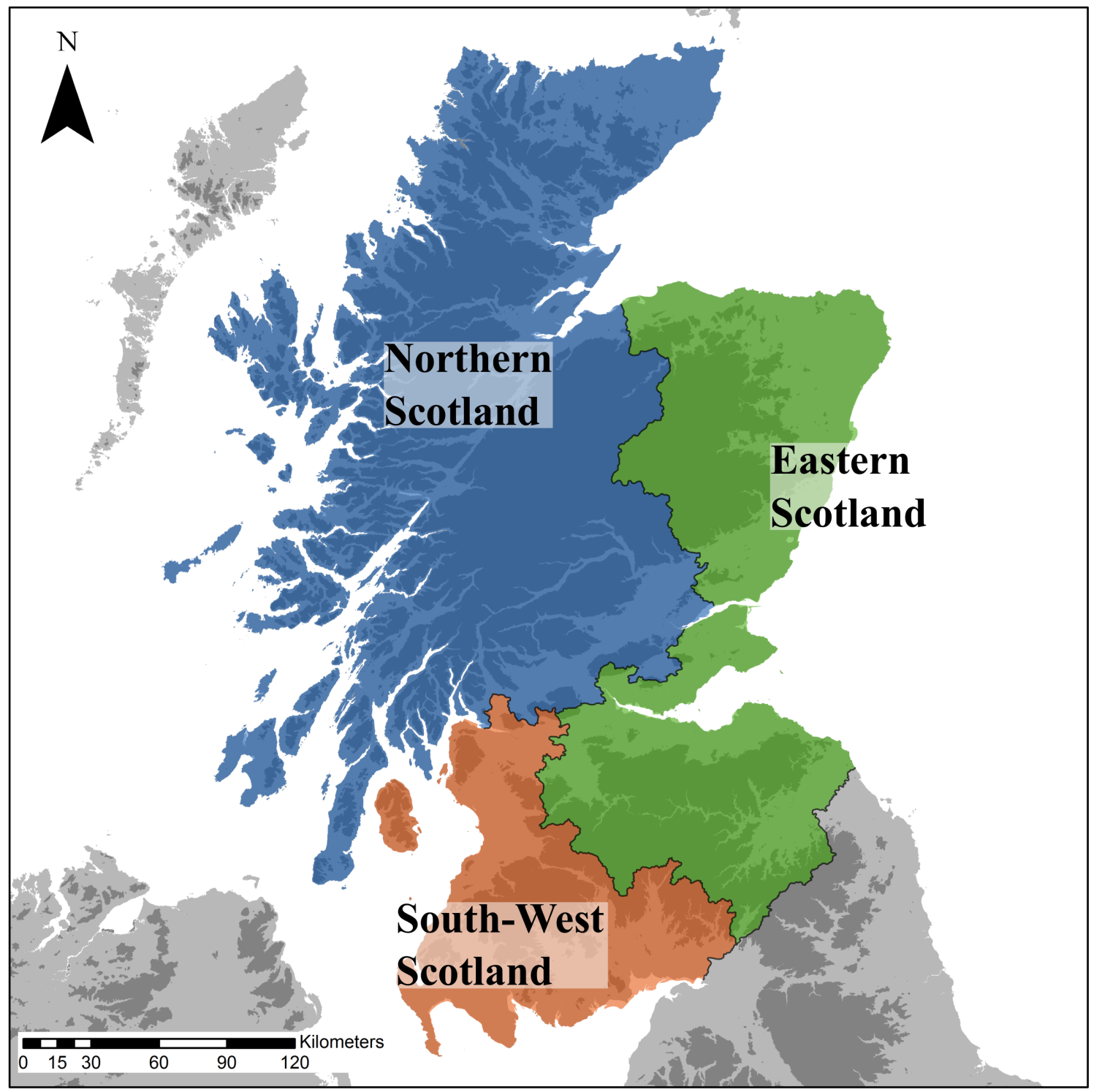

Figure 5 - Modern council areas grouped on basis of similar levels of drainage. 


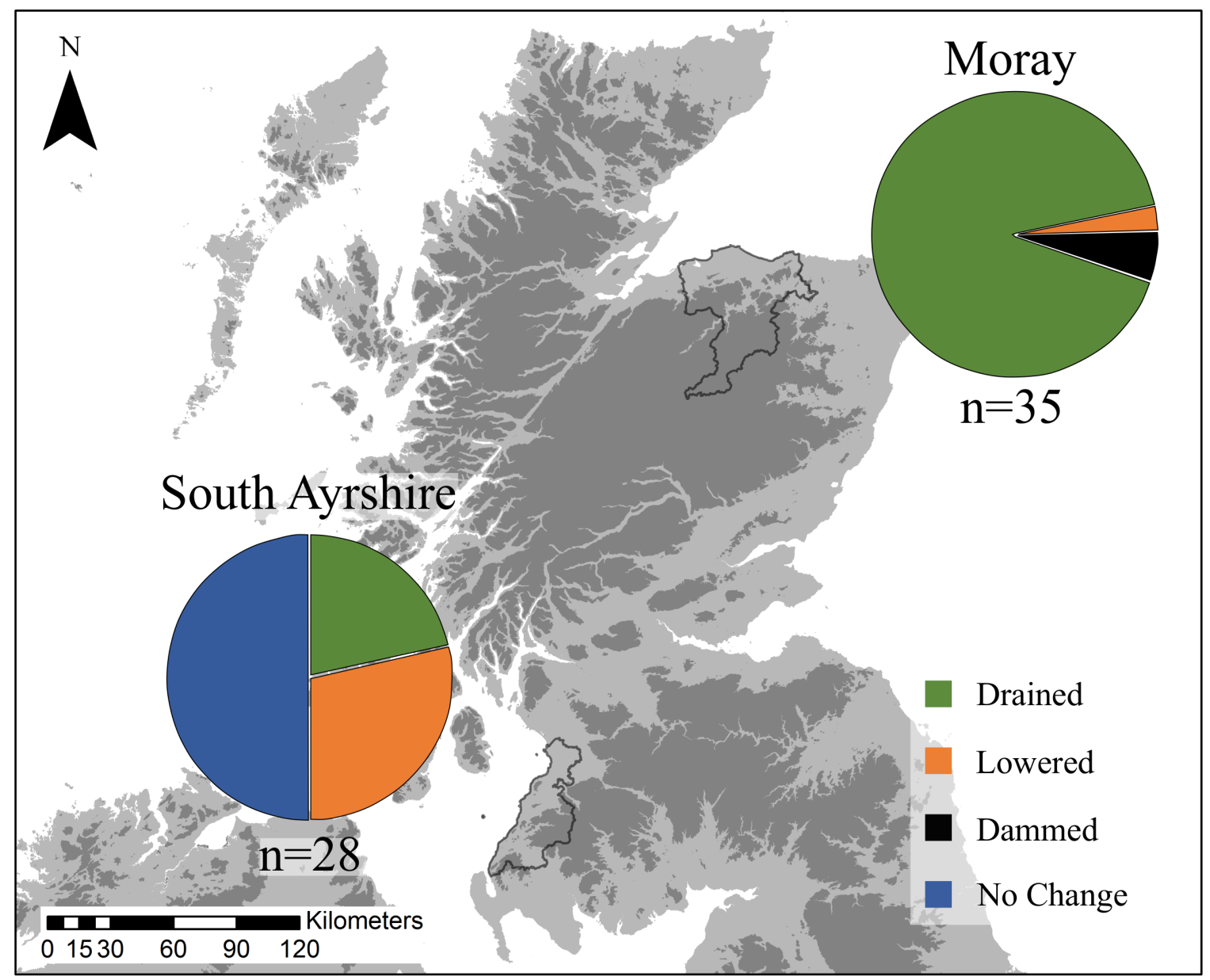

Figure 6 - Comparison of relative loch drainage extent and intensity between Moray and South Ayrshire below 200m ODN. Data within the Supplementary Material can be easily used to compare loch drainage statistics between regions. 


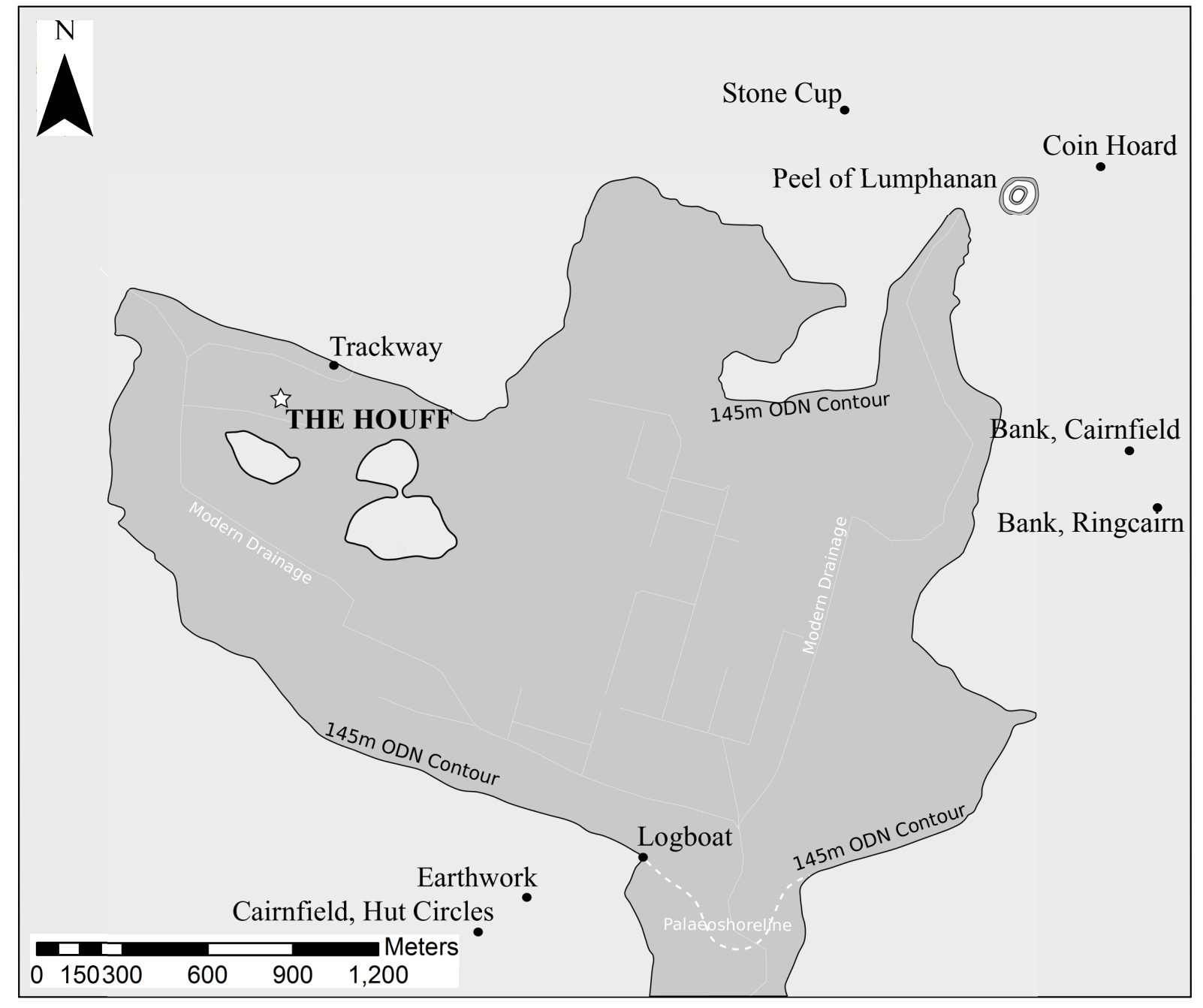

Figure 7 - Possible palaeoshoreline of the former Loch Auchlossan at 145m ODN. Note the lack of recorded archaeological features from within the proposed extent of the former loch, with the exception of the Houff. Height data extracted from 5x5m Ordnance Survey Digital Terrain Model (C) Crown Copyright. 


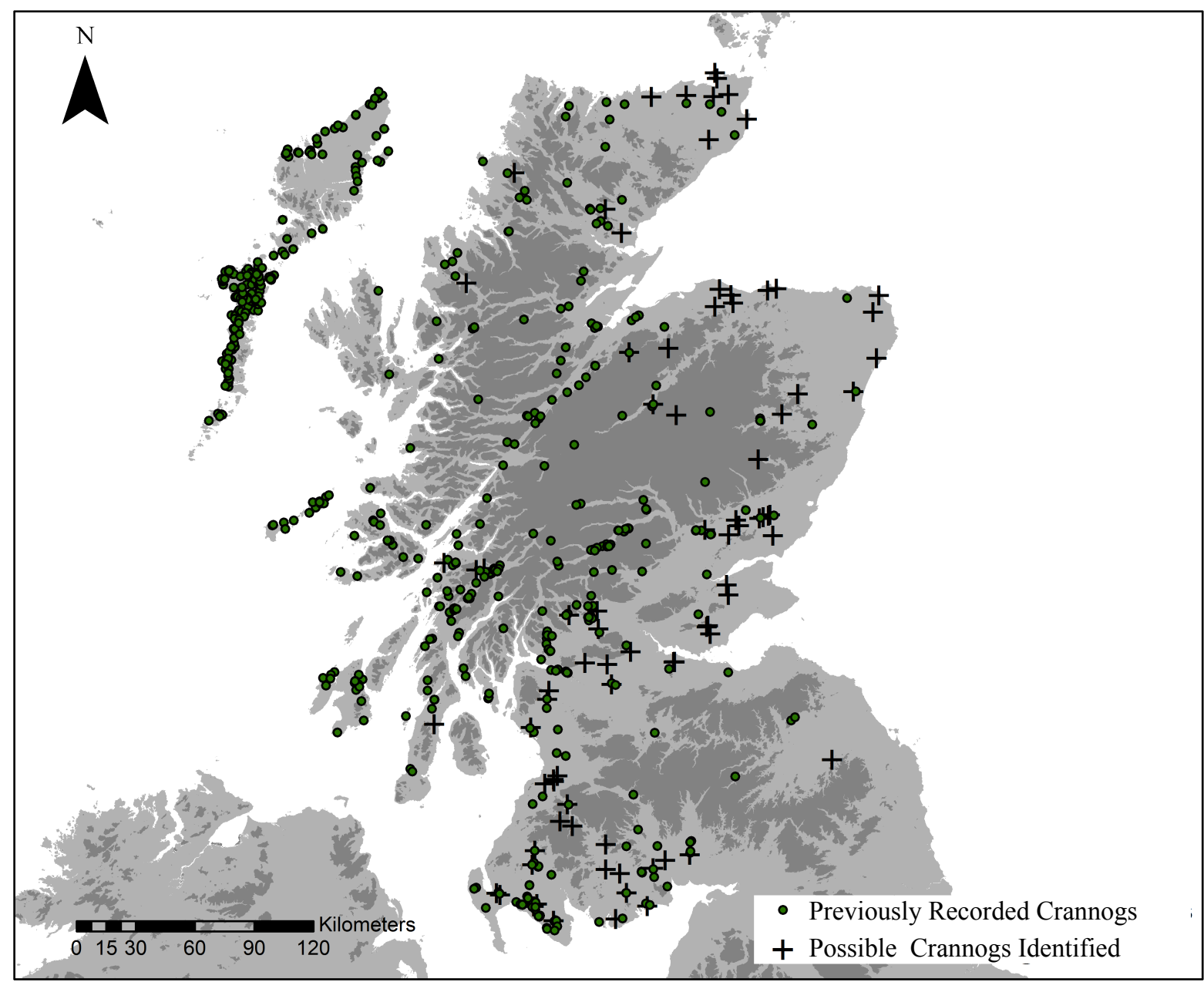

Figure 8 - Distribution of recorded crannogs (Cavers 2010; Lenfert 2012), and recorded archaeological sites considered as possible crannogs based on their location within or likely within former or lowered lochs (after Stratigos 2016). 
Table 1 - Criteria for assessing drainage of lochs depicted on the RMS.

\begin{tabular}{ll}
\hline Category & Description \\
\hline Drained & $\begin{array}{l}\text { where the loch was totally removed or lowered to a point where there is no } \\
\text { open water }\end{array}$ \\
Lowered & $\begin{array}{l}\text { where the surface area of the loch was reduced with evidence for effective } \\
\text { drainage activity }\end{array}$ \\
No & $\begin{array}{l}\text { where the surface area of the loch has not changed and there is no evidence of } \\
\text { effective drainage activity }\end{array}$ \\
Dammed & $\begin{array}{l}\text { where there is evidence for the construction of a dam which increases the } \\
\text { surface area of the loch }\end{array}$
\end{tabular}

Table 2 - Sample table of results.

\begin{tabular}{|c|c|c|c|c|c|c|c|c|}
\hline Loch & $\begin{array}{l}\text { Presen } \\
\text { t State }\end{array}$ & $\begin{array}{l}\text { OS } \\
\text { Six } \\
\text { Inch } \\
1843- \\
1882\end{array}$ & Council & $\begin{array}{l}\text { RMS } \\
\text { Online } \\
\text { Ref }\end{array}$ & $\begin{array}{l}\text { Eastin } \\
\mathrm{g}\end{array}$ & $\begin{array}{l}\text { Northin } \\
\mathrm{g}\end{array}$ & $\begin{array}{l}\text { Heig } \\
\text { ht } \\
\text { abov } \\
\text { e OD } \\
\text { (New } \\
\text { lyn) } \\
(\mathrm{m})\end{array}$ & $\begin{array}{l}\text { RMS } \\
\text { Sectio } \\
n\end{array}$ \\
\hline $\begin{array}{l}\text { Loch of } \\
\text { Kininmonth }\end{array}$ & $\begin{array}{l}\text { Draine } \\
\mathrm{d}\end{array}$ & $\begin{array}{l}\text { Lower } \\
\text { ed }\end{array}$ & $\begin{array}{l}\text { Aberdeens } \\
\text { hire }\end{array}$ & $\begin{array}{l}\text { NK } 033 \\
541\end{array}$ & $\begin{array}{l}40121 \\
2\end{array}$ & 854482 & 81 & $\begin{array}{l}\text { Highla } \\
\text { nd }\end{array}$ \\
\hline $\begin{array}{l}\text { Loch an } \\
\text { Daimh }\end{array}$ & $\begin{array}{l}\text { No } \\
\text { Chang } \\
\text { e }\end{array}$ & $\begin{array}{l}\text { No } \\
\text { Chang } \\
\text { e }\end{array}$ & $\begin{array}{l}\text { Argyll and } \\
\text { Bute }\end{array}$ & $\begin{array}{l}\text { NM } 846 \\
091\end{array}$ & $\begin{array}{l}18609 \\
8\end{array}$ & 710943 & 259 & $\begin{array}{l}\text { Highla } \\
\text { nd }\end{array}$ \\
\hline Heart Loch & $\begin{array}{l}\text { Draine } \\
\text { d }\end{array}$ & $\begin{array}{l}\text { Lower } \\
\text { ed }\end{array}$ & $\begin{array}{l}\text { South } \\
\text { Ayrshire }\end{array}$ & $\begin{array}{l}\text { NS } 300 \\
098\end{array}$ & $\begin{array}{l}23105 \\
7\end{array}$ & 609422 & 52 & $\begin{array}{l}\text { Lowla } \\
\text { nd }\end{array}$ \\
\hline
\end{tabular}

